\title{
Ritkábban előforduló, alsó légúti fertőzést okozó Gram-negatív nem fermentáló pálcák
}

\author{
Juhász Emese dr. - Iván Miklós dr. \\ Pongrácz Júlia dr. - Kristóf Katalin dr. \\ Semmelweis Egyetem, Laboratóriumi Medicina Intézet, \\ Klinikai Mikrobiológiai Diagnosztikai Laboratórium, Budapest
}

\begin{abstract}
Bevezetés: A nem fermentáló Gram-negatív baktériumok a környezetben széles körben elterjedtek. Többségükkel opportunista, nosocomialis patogénként találkozunk a klinikai gyakorlatban. A csoport jól ismert tagjai (például a Pseudomonas vagy az Acinetobacter fajok) mellett ritkább fajok is identifikálásra kerülnek, különösen, mióta a klinikai mikrobiológiai gyakorlatba bevezetésre került a „mátrix-asszisztált lézer deszorpciós-ionizációs, repülési idő mérésén alapuló tömegspektrometria" (MALDI-TOF MS) technika. A ritkábban előforduló Gram-negatív baktériumok döntő része légúti mintákból kerül izolálásra. Klinikai jelentőségük az alsó légúti fertőzésekben, akárcsak klinikai mikrobiológiai vizsgálatuk szabályai, egyelőre tisztázatlanok.

Célkitüzés: Néhány fontosabb, ritkábban előforduló, alsó légúti fertőzést okozó Gram-negatív pálca klinikai mikrobiológiai jellemzése.

Módszer: Négy év adatainak retrospektív feldolgozásával áttekintettük a nem fermentáló Gram-negatív baktériumok alsó légúti fertőzésekben potenciálisan betöltött szerepét és antibiotikum-érzékenységét a Semmelweis Egyetemen. Összesen 3589 beteg alsó légúti mintáit elemeztük a 2013-2016 négyéves periódusban. A baktériumok azonosítása minden esetben MALDI-TOF MS módszerrel, az antibiotikum-érzékenységi vizsgálat pedig döntően korongdiffúziós módszerrel történt.

Eredmények: A Pseudomonas aeruginosát követően a Stenotrophomonas maltophilia volt a második, míg az Acinetobacter baumannii a harmadik leggyakrabban azonosított nem fermentáló Gram-negatív baktérium az alsó légúti mintákban. Összesen 742 olyan izolátumot azonosítottunk, melyek a ritka nem fermentáló pálcák csoportjába tartoztak. Az izolátumok 23\%-a Achromobacter xylosoxidans volt. A Chryseobacterium, Rhizobium, Delftia és Elizabethkingia fajok mellett néhány Ralstonia és Ochrobactrum, valamint egy-egy egyéb baktériumfajt azonosítottunk. A pontos fajazonosítás kiemelt jelentőségü, mivel e baktériumok nagy része természetes aminoglikozid-rezisztenciával bír. Gyakran rezisztensek ceftazidimre, cefepimre, piperacillin/tazobactamra és karbapenemekre is.

Következtetések: Összességében a ciprofloxacin, a levofloxacin és a trimethoprim/sulfamethoxazol bizonyult a leghatékonyabbnak a csoport tagjaival szemben.
\end{abstract}

Orv Hetil. 2018; 159(1): 23-29.

Kulcsszavak: Gram-negatív aerob baktérium, bakteriális pneumonia, antimikrobiálisgyógyszer-rezisztencia, MALDI, Stenotrophomonas maltophilia

\section{Uncommon non-fermenting Gram-negative rods as pathogens of lower respiratory tract infection}

Introduction: Glucose non-fermenting Gram-negative bacteria are ubiquitous environmental organisms. Most of them are identified as opportunistic, nosocomial pathogens in patients. Uncommon species are identified accurately, mainly due to the introduction of matrix-assisted laser desorption-ionization time of flight mass spectrometry (MALDI-TOF MS) in clinical microbiology practice. Most of these uncommon non-fermenting rods are isolated from lower respiratory tract samples. Their significance in lower respiratory tract infections, such as rules of their testing are not clarified yet.

Aim: The aim of this study was to review the clinical microbiological features of these bacteria, especially their roles in lower respiratory tract infections and antibiotic treatment options.

Method: Lower respiratory tract samples of 3589 patients collected in a four-year period (2013-2016) were analyzed retrospectively at Semmelweis University (Budapest, Hungary). Identification of bacteria was performed by MALDITOF MS, the antibiotic susceptibility was tested by disk diffusion method. 
Results: Stenotrophomonas maltophilia was revealed to be the second, whereas Acinetobacter baumannii the third most common non-fermenting rod in lower respiratory tract samples, behind the most common Pseudomonas aeruginosa. The total number of uncommon non-fermenting Gram-negative isolates was 742 . Twenty-three percent of isolates were Achromobacter xylosoxidans. Beside Chryseobacterium, Rhizobium, Delftia, Elizabethkingia, Ralstonia and Ochrobactrum species, and few other uncommon species were identified among our isolates. The accurate identification of this species is obligatory, while most of them show intrinsic resistance to aminoglycosides. Resistance to ceftazidime, cefepime, piperacillin-tazobactam and carbapenems was frequently observed also.

Conclusions: Ciprofloxacin, levofloxacin and trimethoprim-sulfamethoxazole were found to be the most effective antibiotic agents.

Keywords: Gram-negative aerobic bacteria, bacterial pneumonia, bacterial drug resistance, mass spectrometry, matrix-assisted laser desorption-ionization (MALDI), Stenotrophomonas maltophilia

Juhász E, Iván M, Pongrácz J, Kristóf K. [Uncommon non-fermenting Gram-negative rods as pathogens of lower respiratory tract]. Orv Hetil. 2018; 159(1): 23-29.

(Beérkezett: 2017. szeptember 4.; elfogadva: 2017. szeptember 15.

\section{Rövidítések}

$\mathrm{AN}=$ amikacin $; \mathrm{CAZ}=$ ceftazidim $; \mathrm{CF}=$ cystás fibrosis $; \mathrm{CIP}=$ ciprofloxacin; EUCAST = European Committee on Antimicrobial Susceptibility Testing; FEP = cefepim; GE = gentamicin; IMP = imipenem; LEV = levofloxacin; MALDI-TOF MS = mátrix-asszisztált lézer deszorpciós-ionizációs, repülési idő mérésén alapuló tömegspektrometria; $\mathrm{MEM}=$ meropenem; SXT $=$ trimethoprim $/$ sulfamethoxazol; $\mathrm{TO}=$ tobramycin; $\mathrm{TZP}=$ piperacillin/tazobactam; VAP = lélegeztetéssel összefüggő pneumonia

Az Orvosi Hetilapban egy 2014-ben megjelent közleményben már beszámoltak arról, hogy milyen jelentős változást hozott a klinikai mikrobiológiai gyakorlatba a mátrix-asszisztált lézer deszorpciós-ionizációs, repülési idő mérésén alapuló tömegspektrometria (MALDI-TOF MS) [1] . A baktériumok és gombák azonosítása nemcsak gyorsabbá, hanem pontosabbá is vált. A glükózt nem fermentáló, egymáshoz biokémiai profiljukban nagymértékben hasonló Gram-negatív baktériumfajok esetében a MALDI-TOF MS-en alapuló diagnosztika bevezetése szignifikáns változást hozott. Olyan fajok azonosítása vált lehetővé, melyek korábban szinte csak molekuláris módszerekkel kerültek identifikálásra. Bár a nagyszámú biokémiai próbát alkalmazó automata identifikáló rendszerek a nem fermentáló pálcák széles spektrumát képesek azonosítani, sokszor szembesül a mikrobiológus azzal, hogy az identifikálási eredmény konfidenciaszintje alacsony vagy több lehetséges faj közel azonos konfidenciaszinttel kerül megállapításra, a baktériumok közel azonos biokémiai profilja miatt. Az elsősorban a konzervált riboszomális fehérjék tömegspektrometriás mérésén alapuló MALDI-TOF technika ezt a bizonytalanságot kiküszöbölte és többnyire pontos fajszintű azonosítást tett lehetővé.

A glükózfermentálás hiányával és az oxidatív cukorbontással általánosan jellemezhető Gram-negatív bakté- riumcsoport tagjai a környezetben, fóleg vizes közegekben széles körben elterjedtek. Többségük nosocomialis, opportunista patogén. Klinikai mintákból történő identifikálásuk esetén a környezeti kontamináció lehetősége mindig felmerül [2]. További dilemma, hogy az adott baktérium csak kolonizálóként van jelen a betegben, vagy valós patogén. Főleg a molekuláris vizsgálatoknak köszönhetôen a csoport taxonómiája sokat változott az elmúlt évtizedekben. Korábban többnyire a Pseudomonas genusba történt besorolásuk, elnevezésük is valamilyen Pseudomonas vagy Flavobacterium speciesként történt. A jelenlegi taxonómia sem tekinthetó véglegesnek, főként a teljesgenom-szekvenálási eredményektől függően újabb változások várhatók.

A ritkább Gram-negatív nem fermentáló pálcák döntő része légúti mintákból kerül izolálásra. Kóroki szerepüket elsősorban krónikus légúti betegek körében sokat vizsgálják. A Gram-negatív nem fermentáló pálcák csoportjának legtöbbet vizsgált tagja a Pseudomonas aeruginosa, melynek kóroki szerepe a cystás fibrosisban (CF) szenvedő betegekben ma már evidencia. A sokszor multirezisztens Acinetobacter baumannii - mint a nosocomialis pneumonia kórokozója - sem szorul bemutatásra. A Burkholderia fajok is régóta ismert légúti patogének, de a tüdőtranszplantációs irányelvek megjelenésével új jelentőséget kaptak. Stenotrophomonas maltophiliával (korábban Xanthomonas maltophilia vagy Pseudomonas maltophilia) is egyre gyakrabban találkoznak az alsó légúti fertőzésben szenvedő betegeket gyógyító klinikusok. A felsorolt négy baktérium antibiotikum-érzékenységét a klinikai mikrobiológiai laboratóriumok az egységes európai ajánlásnak (a European Committee on Antimicrobial Susceptibility Testing: EUCAST szabályainak) megfelelóen vizsgálják és interpretálják [3]. A csoport többi, ritkább tagjának vizsgálata és az eredmények interpretálása azonban kérdéses, mivel jelenleg még nincs vonatkozó EUCAST-ajánlás. Általában a Pseudomonas fajoknak megfelelő antibiotikum-érzékenységi vizsgálatot 
végzi a laboratórium, és az eredményeket is a Pseudomonas fajokra vonatkozó antibiotikum-érzékenységi határértékek, esetleg a nem-fajspecifikus határértékek alapján interpretálja.

Az előbbiek feltételei, hogy a baktérium a mintából izolálásra kerüljön, melyhez olykor a rutintól eltérő, meghosszabbított tenyésztés szükséges (>2 nap), a baktériumot pontosan identifikálják (például MALDI-TOF MS-sel) és mérlegeljék klinikai jelentőségét. A baktérium alsó légúti mintában való csíraszáma, illetve a mintából készített kenet mikroszkópos értékelése, azon belül a fehérvérsejtek laphámsejtekhez vagy bronchus-hámsejtekhez viszonyított aránya vezeti a mikrobiológust, hogy a kolonizáló vs. infekciót okozó patogén kérdésében állást foglaljon, de ezt valójában csak a klinikus tudja eldönteni. Az ilyen nehezebben vizsgálható baktériumok negligálása, klinikai szignifikanciájuk önkényes kizárása a mikrobiológus részéról súlyos hiba. Inkább jelenjen meg egy „különös” baktérium a leleten „a kolonizáló flóra része?” vagy „kontamináció?” megjegyzéssel, mint hogy egyáltalán ne kerüljön a klinikus tudomására. Az így esetleg megnyíló, laboratóriumi szakember és klinikus közti párbeszéd csak előrevivő, a beteg érdekét szolgáló lehet. A lelet kiegészítése egyéb információval (pl. baktériumfaj neve mellett a nagyobb rendszertani egység megnevezése) segítheti a klinikust.

Bár egyre többet tudunk meg a ritkább nem fermentáló baktériumok kóroki szerepéről, klinikai jelentőségük az alsó légúti fertőzésekben, akárcsak klinikai mikrobiológiai vizsgálatuk szabályai máig nagyban tisztázatlanok. Ez késztette a szerzőket arra, hogy az elmúlt évek eredményeit áttekintve elemezzék e baktériumok klinikai mikrobiológiai sajátosságait, különös tekintettel azok alsó légúti mintákban való előfordulására és az antibiotikus kezelés lehetőségeire.

\section{Módszer}

A Semmelweis Egyetem Laboratóriumi Medicina Intézetének mikrobiológiai laboratóriumában 2012-ben került bevezetésre a MALDI-TOF MS technika, ezért az ezt követô évek eredményeit vontuk be vizsgálatunkba. Négy év (2013-2016) tenyésztési és identifikálási eredményeit retrospektív módon elemeztük. Az elemzés alapjául a laboratórium informatikai rendszerében (MedBakter) rögzített leletek szolgáltak. A köpet, bronchoalveolaris lavage, bronchus- és trachea-aspirátum mintaként jelölt anyagokat tekintettük alsó légúti eredetűnek. A mintákból készült Gram-festett kenet eredményét (fehérvérsejt:laphámsejt arány) minden esetben figyelembe vettük. A bakteriológiai tenyésztés véres, csokoládé és eozin-metilénkék táptalajokon történt. Tüdőtranszplantált és CF-betegek esetében mintáikat folyékony táplevesben is tenyésztettük. A táptalajok inkubálási ideje a beutaló iránydiagnózistól és a klinikus megjegyzésétől függően változott: rutinszerűen 48 óra, tüdőtranszplantáltak, CF-betegek, súlyos krónikus légúti betegségben (COPD, bronchiectasia stb.) szenvedő ismert betegek esetében pedig legalább 5 nap volt. A MALDI-TOF MS (Bruker) identifikálás eredményét $>2.0$ érték esetén fogadtuk el. Az antibiotikum-érzékenységi vizsgálatok korongdiffúziós módszerrel történtek. A Pseudomonas fajokra jellemző antibiotikumokat: imipenem (IMP), meropenem (MEM), piperacillin/ tazobactam (TZP), ceftazidim (CAZ), cefepim (FEP), gentamicin (GE), tobramycin (TO), amikacin ( $\mathrm{AN})$, ciprofloxacin (CIP), levofloxacin (LEV), ezenkívül a trimethoprim/sulfamethoxazolt (SXT) vizsgáltuk. Az EUCAST Pseudomonas fajokra specifikus, SXT esetében pedig az Acinetobacter spp. specifikus gátlási zóna átmérôi alapján interpretáltuk az eredményeket. Egy baktériumfajra vonatkozóan minden betegtől csak egy, az adott évben az első, alsó légúti mintájából kapott eredményt vontuk a vizsgálatba. Így összesen 3589 beteg alsó légúti mintája került elemzésre.

\section{Eredmények}

A $P$. aeruginosa, S. maltophilia, A. baumannii és az ezektől eltérő, egyéb Gram-negatív nem fermentáló baktérium izolátumok számát és évenkénti eloszlását az 1 . táblázat mutatja be.

Összesen 742 olyan izolátumot azonosítottunk, melyek az egyéb nem fermentáló Gram-negatív pálcák csoportjába tartoztak. Az összes nem fermentáló pálca 20,7\%-át e baktériumok tették ki. Ezek eloszlását és számát a teljes négyéves periódusban a 2. táblázat összegzi.

Az izolált, $P$. aeruginosától különböző Pseudomonas fajokat (P. mosselii, P. monteilii, P. putida, P. alcaliphila, P. otitidis, P. oryzihabitans, P. fulva, P. stutzeri, P. alcaligenes, $P$. mendocina, $P$. fluorescens, $P$. oleovorans) és az $A$. baumanniitól különböző Acinetobacter fajokat ( $A$. pittii, A. junii, A. baylyi, A. johnsonii, A. ursingii, A. haemolyticus, $A$. lwoffii, $A$. tjernbergiae, $A$. calcoaceticus, $A$. radioresistens) egy-egy egységes csoportként ábrázoltuk. Ha egy genusból több faj is előfordult az izoláltak között, akkor csak a genus nevét tüntettük fel.

Néhány kitüntetett baktériumcsoport antibiotikumérzékenységi vizsgálatának eredményeit a 3. táblázatban

1. táblázat Alsó légúti mintákból izolált nem fermentáló Gram-negatív pálcák számának évenkénti eloszlása, 2013-2016

\begin{tabular}{|c|c|c|c|c|c|}
\hline & \multicolumn{4}{|c|}{ Év } & \multirow[t]{2}{*}{ Összesen } \\
\hline & 2013 & 2014 & 2015 & 2016 & \\
\hline Pseudomonas aeruginosa & 337 & 409 & 473 & 361 & 1580 \\
\hline Stenotrophomonas maltophilia & 178 & 243 & 244 & 193 & 858 \\
\hline Acinetobacter baumannii & 95 & 119 & 84 & 111 & 409 \\
\hline $\begin{array}{l}\text { Egyéb nem fermentáló } \\
\text { Gram-negatív pálca }\end{array}$ & 117 & 166 & 255 & 204 & 742 \\
\hline
\end{tabular}


Egyéb nem fermentáló Gram-negatív pálcák száma a teljes négyéves (2013-2016) periódusban

\begin{tabular}{|c|c|c|c|c|c|}
\hline & $\mathrm{n}$ & & $\mathrm{n}$ & & $\mathrm{n}$ \\
\hline Acinetobacter spp. & 142 & Delftia acidovorans & 16 & Brevundimonas diminuta & 4 \\
\hline Pseudomonas spp. & 166 & Elizabethkingia spp. & 11 & Comamonas spp. & 2 \\
\hline Achromobacter xylosoxidans & 171 & Sphingomonas spp. & 10 & Roseomonas spp. & 2 \\
\hline Burkholderia spp. & 117 & Alcaligenes faecalis & 7 & Cupriavidus spp. & 2 \\
\hline Chryseobacterium spp. & 41 & Ralstonia spp. & 7 & Pandorea spp. & 1 \\
\hline \multirow[t]{2}{*}{ Rbizobium spp. } & \multirow[t]{2}{*}{35} & \multirow[t]{2}{*}{ Ochrobactrum spp. } & \multirow[t]{2}{*}{6} & Selenomonas sputigena & 1 \\
\hline & & & & Sphingobacterium multivorum & 1 \\
\hline
\end{tabular}

A félkövér betúvel kiemelt baktériumokat tárgyaljuk lentebb.

3. táblázat | Néhány kiemelt baktériumfaj antibiotikumrezisztencia-vizsgálatának összefoglaló eredménye

\begin{tabular}{|c|c|c|c|c|c|c|c|c|c|c|c|}
\hline & IMP & MEM & TZP & CAZ & FEP & GE & TO & AN & CIP & LEV & SXT \\
\hline Achromobacter xylosoxidans & $50 \%$ & $86 \%$ & $90 \%$ & $38 \%$ & $\mathrm{R}$ & $\mathrm{R}$ & $\mathrm{R}$ & $\mathrm{R}$ & $\mathrm{R}$ & $30 \%$ & $83 \%$ \\
\hline Chryseobacterium spp. & $\mathrm{R}$ & $\mathrm{R}$ & $88 \%$ & $83 \%$ & $93 \%$ & $\mathrm{R}$ & $\mathrm{R}$ & $\mathrm{R}$ & $90 \%$ & $90 \%$ & $93 \%$ \\
\hline Delftia acidovorans & $88 \%$ & $81 \%$ & $88 \%$ & $94 \%$ & $69 \%$ & $\mathrm{R}$ & $\mathrm{R}$ & $\mathrm{R}$ & $69 \%$ & $69 \%$ & $62 \%$ \\
\hline Elizabethkingia spp. & $\mathrm{R}$ & $\mathrm{R}$ & $18 \%$ & $\mathrm{R}$ & $\mathrm{R}$ & $45 \%$ & $9 \%$ & $18 \%$ & $82 \%$ & $91 \%$ & $100 \%$ \\
\hline Ochrobactrum anthropi & $83 \%$ & $100 \%$ & $\mathrm{R}$ & $\mathrm{R}$ & $\mathrm{R}$ & $66 \%$ & $50 \%$ & $50 \%$ & $100 \%$ & $100 \%$ & $66 \%$ \\
\hline Ralstonia spp. & $\mathrm{R}$ & $57 \%$ & $86 \%$ & $28 \%$ & $57 \%$ & $\mathrm{R}$ & $\mathrm{R}$ & $\mathrm{R}$ & $100 \%$ & $100 \%$ & $100 \%$ \\
\hline Rhizobium radiobacter & $88 \%$ & $94 \%$ & $60 \%$ & $51 \%$ & $71 \%$ & $6 \%$ & $\mathrm{R}$ & $\mathrm{R}$ & $94 \%$ & $88 \%$ & $80 \%$ \\
\hline Sphingomonas spp. & $70 \%$ & $70 \%$ & $60 \%$ & $60 \%$ & $70 \%$ & $90 \%$ & $90 \%$ & $90 \%$ & $80 \%$ & $70 \%$ & $70 \%$ \\
\hline Alcaligenes faecalis & $100 \%$ & $100 \%$ & $100 \%$ & $86 \%$ & $71 \%$ & $\mathrm{R}$ & $\mathrm{R}$ & $\mathrm{R}$ & $57 \%$ & $57 \%$ & $71 \%$ \\
\hline
\end{tabular}

$>90 \% \quad 75-90 \% \quad 50-75 \% \quad 25-50 \% \quad<25 \%$

R: A baktérium természetes rezisztenciája.

A \%-os értékek az adott antibiotikumra érzékeny izolátumok arányát jelölik.

$\mathrm{AN}=$ amikacin $; \mathrm{CAZ}=$ ceftazidim $; \mathrm{CIP}=$ ciprofloxacin $; \mathrm{FEP}=$ cefepim $; \mathrm{GE}=$ gentamicin $; \mathrm{IMP}=$ imipenem; LEV = levofloxacin;

$\mathrm{MEM}=$ meropenem; SXT $=$ trimethoprim/sulfamethoxazol; $\mathrm{TO}=$ tobramycin $; \mathrm{TZP}=$ piperacillin/tazobactam

foglaltuk össze. A baktériumok természetes (intrinsic) rezisztenciáját R-rel jelöltük. A \%-os értékek az adott antibiotikumra érzékeny izolátumok arányát jelölik.

\section{Következtetések}

Közleményünk négy év mikrobiológiai leleteinek retrospektív elemzésével a ritkább nem fermentáló Gram-negatív pálcák előfordulására és megoszlására mutat rá az alsó légúti infekció diagnózis miatt levett mintákban. Ezen baktériumok az antibiotikum-kezelés szempontjából gyakran „probléma baktériumok”, hiszen természetes rezisztenciájuk miatt a szóba jövő antibiotikumok sora eleve a Pseudomonas-ellenes szerekre és az SXT-re szúkül, szerzett rezisztenciájuk folytán pedig könnyen multirezisztenssé válnak. A 2. táblázatban feltüntetett baktériumtörzsek részletes ismertetése meghaladná e közlemény terjedelmét, ezért csak néhányuk (általunk fontosabbnak tartott) tárgyalására szorítkozunk.

\section{Fontosabb, ritkábban elöforduló Gram-negatín pálcák jellemzése}

Az egyéb nem fermentáló Gram-negatív pálcák csoportjából az Achromobacter xylosoxidanst (korábban Alcaligenes xylosoxidans) izoláltuk a leggyakrabban. Az Achromobacter genusba tartozó fajok közül csak az $A$. xylosoxidans fordult elő az elemzett mintákban. Az Achromobacter genus a genomszekvencia alapján leginkább az ismerten légúti infekciókat okozó Bordetella genusszal mutat hasonlóságot. Csillói, biofilmképző képessége, sejtmembrán-lipopoliszacharidja, egyéb membránhoz kapcsolódó alkotói, foszfolipáz-C-, proteáz-, celluláztermelése vagy T3SS apparátusa mind olyan virulenciafaktorok, melyek a légúti gyulladás kialakításában szerepet játszanak. Denitrifikáló képessége lehetôvé teszi, hogy hypoxiás vagy anaerob környezetben is perzisztáljon, szaporodjon. Bronchitist, pneumoniát, empyemát, tüdőtályogot és bronchiectasiához kapcsolódó exacerbatiót egyaránt 
okozhat. A legtöbb klinikai adat eddig a CF-betegek A. xylosoxidans okozta pneumoniája kapcsán gyúlt össze. Tüdőtranszplantált CF-betegekben megfigyelték, hogy a transzplantáció előtt már a betegben lévő pánrezisztens A. xylosoxidans minden esetben, a multirezisztens A. xylosoxidans a betegek egyharmadában rekurrált a transzplantációt követően. A poszttranszplantációs túléléssel azonban nem mutatott összefüggést az $A$. xylosoxidansszal való kolonizáció, ezért az amerikai szerzők szerint ezt nem kell a transzplantáció kizáró okának tekinteni [4]. CF-betegekben az A. xylosoxidans-kolonizáció összefüggést mutat a tüdőfunkció csökkenésével [5]. Gyenge légzésfunkcióval, krónikus légúti betegséggel bíró idős betegekben is számítani lehet kolonizációra [6]. A nem CF-betegek közül elsősorban az egyéb ok miatt bronchiectasiás betegek, a malignus betegségekben, a veseelégtelenségben szenvedók és az immundeficiens betegek számára veszélyeztető. Kórházi környezetben gyakran kerül izolálásra olyan, egyébként steril forrásokból, mint a klór-hexidines oldatok, ultrahangvizsgálathoz használt gélek vagy akár intravénás oldatok. Nosocomialis pneumonia kórokozója lehet. Számos intrinsic (veleszületett) rezisztencia mechanizmussal bír, valamint szerzetten is könnyen rezisztenssé válhat bármely antibiotikumra. $\beta$-laktám antibiotikumokra veleszületetten vagy indukálható módon rezisztens, enzimtermelés (intrinsic blaOXA-144-like, blaOXA-2, blaOXA-243, indukálható cefalosporináz blaAmpC és szerzett karbapenemáz blaIMP) vagy efflux mechanizmus által. Ezek miatt biztosan rezisztensnek kell tekintenünk ampicillinre, amoxycillin/klavulánsavra, I-II. generációs cefalosporinokra, cefotaximra, ceftriaxonra, cefepimre és ertapenemre [7]. Egyéb $\beta$-laktámok esetén az izolátumok variabilitása miatt egyedi vizsgálatuk szükséges. Az Achromobacter fajok aminoglikozidokkal szemben természetes rezisztenciával bírnak (enzimtermelésük és efflux rendszerük miatt). Főleg komplex efflux rendszerük miatt fluorokinolonokra is rezisztenssé válhatnak, egyes ajánlások szerint ciprofloxacinra intrinsic módon rezisztensek [8]. Egyetlen klinikai izolátum teljesgenom-szekvenálásával is egy új, rezisztenciagéneket hordozó transzpozont fedeztek fel [9]. Számos rezisztenciagén rezervoárja lehet [6]. Ezt polimikrobás alsó légúti kolonizáció, illetve infekció esetén érdemes figyelembe venni. Elsőként TZP, MEM vagy SXT a választandó antibiotikum A. xylosoxidans-fertőzésben. A LEV csak MEM-mel kombinációban jön szóba. Másodvonalbeli szer lehet a CAZ. CF-betegek akut exacerbatiója esetén mindig kombinált terápia választandó [8].

Chryseobacterium genus tagjai az Achromobacter fajokhoz hasonlóan elsősorban környezeti, földben és vizes közegben elterjedt baktériumok. A vízcsapok és mosogató-lefolyók, melyeket kórházi környezetben is kolonizálnak, fertőzések potenciális forrásává válhatnak. Biofilmképző képessége és proteáztermelése az invazív fertőzések kialakításában jelentős virulenciafaktorok. Immunkompromittáltak nosocomialis fertőzéseinek kórokozói [10]. Lélegeztetett betegek tracheobronchitis és pneumonia szövődményeiért is felelősek lehetnek. Leggyakrabban a C.gleum és C. indologenes fajok fordultak elő az elemzett mintákban. Érdemes megjegyezni, hogy a C.gleumot újszülöttek alsó légúti fertőzéseiben is leírták kórokozóként [11]. Esetleírásban számoltak már be COPD-s beteg kórházi előzmény nélküli $C$. indologenes-pneumoniájáról [12]. Egyelöre nem tudjuk, hogy a Chryseobacterium fajoknak van-e valamilyen hatása a CFbetegek állapotának alakulására. Feltételezik, hogy a Chryseobacterium spp. által fertőzött CF-betegek nagyobb valószínűséggel fertőzöttek $P$. aeruginosával vagy a $B$. cepacia complex valamely tagjával is [13]. Karbapenemekkel és aminoglikozidokkal szemben természetes rezisztenciát mutatnak $[13,14]$. A CIP, LEV, SXT és FEP eseteink $\geq 90 \%$-ában hatékonynak bizonyult.

A Delftia acidovoransnak (korábban Comamonas acidovorans) ritkán van klinikai jelentősége. Bár ez a baktérium is elsősorban immunkompromittált betegekben okoz pneumoniát, illetve nosocomialis pneumoniát, néhány immunkompetens beteg súlyos $D$. acidovorans-fertőzéséről és empyemáról is beszámol az irodalom [15]. Aminoglikozidokkal szemben természetes rezisztenciát mutat. Teljesgenom-szekvenálással a $\beta$-laktamáz és aminoglikozid foszfotranszferáz gének mellett olyan $g y r A$, $\operatorname{gyr} B, \operatorname{par} A$ és parC génmutációkat azonosítottak, melyek kinolonokkal szembeni rezisztenciát eredményeztek [16]. A vizsgált izolátumok CAZ-re voltak legmagasabb arányban érzékenyek, de az IMP, MEM és TZP is $\geq 80 \%$ ban hatékonynak bizonyult.

Az Elizabethkingia genus (korábban Chryseobacteri$u m)$ tagjai közül az E. meningoseptica és az E. miricola fordult elő a vizsgált mintákban. Nosocomialis légúti fertőzések, például lélegeztetéssel összefüggő pneumonia (VAP), súlyos pneumonia, tüdőtályog kórokozói lehetnek. Széles spektrumú antibiotikus kezelést követően perzisztáló légúti kolonizációt okozhatnak. Bontó enzimek intrinsic termelése miatt rezisztensek az összes $\beta$-laktám antibiotikumra [7]. Kérdéses, hogy a piperacillin/tazobactamban lévő tazobactam gátolja-e in vivo ezen enzimek hatását. Egy fatális kimenetelű nosocomialis pneumoniából izolált E. miricola teljesgenom-szekvenálással feltárt rezisztomjából - mely összesen 40 rezisztenciagént tartalmazott - kiderült, hogy nagyszámú $\beta$-laktamázt, különböző karbapenemázokat (metallo- $\beta$ laktamázt) és aminoglikozid transzferázt termelnek. Szulfonamid-, tetracyclin- és kloramfenikol-rezisztens génjeik tovább szúkítik a hatékony antibiotikumok spektrumát [17]. Fluorokinolon-érzékenységük speciesfüggő: az E. meningoseptica izolátumok többsége rezisztens, míg az E. miricola (a CIP kivételével) többnyire érzékeny. Több sikeres SXT-terápiáról számoltak be [18]. Eredményünk, miszerint minden izolátum SXTérzékeny volt, alátámasztja az irodalmi adatokat.

Ralstonia pickettii (korábban Burkholderia pickettii) és R. mannitolytica (korábban Pseudomonas thomasii) fajok is kerültek izolálásra a vizsgált alsó légúti minták- 
ból. Tápszegény környezethez adaptálódó, akár desztillált vízben is túlélő baktériumok. Feltételezhető, hogy a Ralstonia spp. általi fertőzések (a Brevundimonas diminuta-fertőzésekhez hasonlóan) a kontaminált vízből erednek. E fajok fertőtlenítőszerekkel, például klór-hexidinnel szembeni rezisztenciája megnehezíti kórházi közegekből való eliminálásukat. Enyhe légúti tünetekkel járó $R$. pickettii-járványt már leírtak. Újszülöttekben és különböző rizikófaktorokkal bíró betegekben (diabetes, krónikus granulomatosus betegség, Burkitt-lymphoma) Ralstonia okozta pneumonia eseteiról számol be az irodalom. CF-betegekben ismert patogén, COPD-s betegekben akut exacerbatiót okozhat [19]. Két D-osztályú $\beta$-laktamázt, a bla $a_{\mathrm{OXA}-22}$ és bla ${ }_{\mathrm{OXA}-60}$ típusokat azonosították $R$. pickettiiben. Utóbbi a baktérium IMP-rezisztenciájáért felelős [20]. Izolátumaink mindegyike érzékeny volt CIP-ra, LEV-ra és SXT-ra. Bár in vitro IMP-érzékenynek bizonyultak, tekintettel OXA-60 $\beta$-laktamáz termelésükre az IMP-terápia nem javasolható.

Az Ochrobactrum anthropi a Brucella genusszal közeli rokon opportunista patogén. Identifikálása és megkülönböztetése a Brucella fajoktól és más Ochrobactrum fajoktól a rutin biokémiai tesztekkel a nagyfokú fenotípusos hasonlóság miatt nem lehetséges. A $O$. anthropifertőzések nagyon ritkán manifesztálódnak alsó légúti fertőzésként. Csak néhány esetről számoltak be eddig [21]. Krónikus fertőzést nem okoz. Imipenem és MEM kivételével intrinsic módon rezisztens az összes $\beta$-laktám antibiotikumra, bontó enzimek termelése miatt [7]. Az irodalmi in vitro eredmények alapján empirikus terápiaként CIP és/vagy SXT ajánlható [22]. Eredményeink szerint minden vizsgált izolátum érzékeny volt CIP-ra, LEV-ra és MEM-re.

A Rhizobium (korábban Agrobacterium) radiobacter a talajban élö növényi patogén, mely alacsony virulenciájú humán kórokozóként is ismert. Nincs minden esetben klinikai szignifikanciája, a legtöbb humán fertőzés közösségben szerzett, számos kockázati tényezővel rendelkező betegeket érint (krónikus betegek, bármely okból immunkompromittáltak). Ubiquitaer természete miatt kórházi környezetben is számítani lehet jelenlétére. Ellentmondóak az irodalmi adatok a baktérium betegek közötti terjedésének lehetőségéről. Biofilmképzése a legfontosabb virulenciafaktora, így a kanülök sok esetben jelentik a $R$. radiobacter okozta véráramfertőzések eredőjét [23]. Légúti patogén szerepük nem egyértelmü, csak egy-egy esetismertetés lelhetô fel az irodalomban [24]. A baktérium tobramycinre és amikacinra intrinsic módon rezisztens, aminoglikozid acetiltranszferáz termelése miatt. A CAZ, FEP, TZP, a fluorokinolonok és a karbapenemek a leggyakrabban használt antibiotikumok R. radiobacter-fertőzésekben [25]. Saját adataink az irodalmi értékekkel megegyeznek: a 90\% feletti MEM- és CIP-érzékenység alapján ez a két antibiotikum javasolható empirikus terápiaként.

A Sphingomonas (korábban Pseudomonas) fajok közül a $S$. paucimobilis és $S$. parapaucimobilis fordult elö a vizs- gált mintákban. Nosocomialis fertőzések, köztük VAP, pneumonia és empyema kórokozóiként is ismertek. Többnyire a kontaminált vizes közegek a fertőzések forrásai. Empirikus terápiaként aminoglikozid plusz karbapenem vagy CAZ javasolható [26]. Az izolátumok 90\%os aminoglikozid-érzékenysége alapján ezt a javaslatot eredményeink megerősítik.

Meglepő eredmény, hogy a S. maltophilia az alsó légúti fertőzés miatt vett mintákban a második leggyakrabban azonosított baktérium a nem fermentáló pálcák csoportjából. A kórokozóval kapcsolatban csak néhány, a terápiára vonatkozó megállapítást ismertetünk. Az SXTterápiát a mikrobiológiai laboratórium specifikus érzékenységi határérték alapján tudja alátámasztani [3]. Abban az esetben, ha a $S$. maltophilia izolátum SXT-rezisztens, vagy ha a beteg gyógyszer-túlérzékenység vagy egyéb ok miatt SXT-kezelést nem kaphat, elsősorban fluorokinolon, azon belül levofloxacin- vagy moxifloxacin-terápia jön szóba. Ez utóbbi esetekben a mikrobiológus egyelőre csak nem specifikus határértékek alapján tudja interpretálni a rezisztenciavizsgálatok eredményeit. Doxycyclin-, tigecyclin- vagy chloramphenicol-terápia alternatíva lehet, de ezen esetekben is csak epidemiológiai vágóértékekre (ECOFF) vagy az amerikai ajánlásra hagyatkozhatunk.

\section{Egyéb antibiotikum-kezelési lehetôségek}

Hiányolhatja az olvasó az említett antibiotikumok sorából a colistint, mint a multirezisztens $P$. aeruginosa-és $A$. baumannii-fertőzések esetében gyakran használt gyógyszert. Korábbi eredményeink azt mutatják, hogy a $S$. maltophilia izolátumok $>90 \%$-a nagyfokú rezisztenciát mutat colistinnel szemben [27]. Az egyéb nem fermentáló pálcák colistinérzékenysége a rutindiagnosztika során nem került vizsgálatra, hiszen a közelmúltig a colistinérzékenységi vizsgálat metodikájára vonatkozó ajánlás nem volt, továbbá az eredmények interpretálása e baktériumcsoport esetén jelenleg is tisztázatlan. Irodalmi adatok az $A$. xylosoxidans esetén $28-70 \%$-os in vitro colistinérzékenységről számolnak be [8]. A colistin inhalációs terápia szisztémás MEM-mel kombinálva alternatív kezelési stratégia alsó légúti $A$. xylosoxidans-fertőzésekben. A legtöbb Chryseobacterium izolátum colistinrezisztens. Megfigyelték, hogy a kórházban használt colistin és tigecyclin mennyiségével arányosan növekedett a C. indologenes-fertőzések gyakorisága [14]. A D. acidovorans colistinrezisztens [28], ahogy az Elizabethkingia fajok és az O. anthropi is [17, 22].

A tetracyclinek csoportjából légúti fertőzések esetében felmerül a tigecyclin-, illetve az amerikai ajánlásban szereplő, de Magyarországon nem fogalmazott minocyclinterápia lehetősége. Egyelőre ugyanazt kell, hogy megfogalmazzuk, mint a colistin esetében: sem vizsgálatukra, sem az eredmények interpretálására vonatkozó ajánlás nincsen. Korábbi vizsgálatunkban a $S$. maltophilia törzsek in vitro 70\%-ban tigecyclin-rezisztensnek bizonyul- 
tak. Irodalmi adatok alapján tigecyclin-rezisztenciára kell számítani E. miricola esetében is.

$\mathrm{Az}$ inhalációs formában alkalmazható antibiotikumok CF-betegek és egyéb, bronchiectasiában szenvedő betegek esetén is terápiás alternatívát jelentenek. Az intenzív terápiás gyakorlatban a VAP kezelése kapcsán merülnek fel lehetőségként az aeroszolizált vagy porlasztott antibiotikumok. A mikrobiológiai gyakorlatban jelenleg használt klinikai érzékenységi határértékek a szisztémás antibiotikus kezeléssel elérhető plazma-gyógyszerkoncentrációkon alapulnak. Ezek az értékek nem reprezentálják a szisztémás kezeléssel a tüdőszövetben elérhető gyógyszerszinteket, ahogy az inhalációs kezeléssel elérhető lényegesen magasabb gyógyszer-koncentrációkat sem. Külön határértékek megállapítása lenne szükséges az inhalációs formában alkalmazott antibiotikumokra. Inhalációs TO esetében alkalmazandó, $P$. aeruginosa-specifikus határértékre már tettek ajánlást, de ez egyelőre nem került bele a közös európai ajánlásba [29]. Inhalációs formájú GE, AN, CIP, LEV, colistin és aztreonam esetén még $P$. aeruginosa-specifikus ajánlás sincs. A nem fermentáló Gram-negatív pálcák körében gyakori magas fokú aminoglikozid- és colistinrezisztencia miatt e készítmények monoterápiaként valószínúleg nem alkalmasak az alsó légúti fertőzések kezelésére, de az elérhető igen magas légúti koncentrációjuk miatt szisztémás antibiotikumokkal kombinálva szinergista hatásuk lehet, valamint segíthetik a légúti biofilmben perzisztáló baktériumok eradikálását [30, 31].

A MALDI-TOF MS technika elterjedésével a közeljövőben várhatóan pontosabban fogjuk tudni e baktériumok valós incidenciáját. A krónikus légúti betegek körében végzett mikrobiom-kutatások eredményeitől és az egyes baktériumok teljesgenom-szekvenciájának elemzéseitől egyaránt várható, hogy e baktériumcsoport klinikai szerepéről és a fertőzések kezelési lehetőségeiről többet megtudunk. A vizsgálandó antibiotikumok sorára, a vizsgálatok metodikájára és az eredmények interpretálására vonatkozó európai ajánlás még várat magára, pedig sürgősen szükséges lenne. Fontos és valószínúleg egyre jelentősebb baktériumcsoportról van szó. A klinikusoknak mérlegelniük kell egy-egy ritkább nem fermentáló Gram-negatív pálca lehetséges kóroki szerepét és a megfelelő antibiotikum-kezelési stratégiát, melyhez a gondos mikrobiológiai vizsgálat adhat segítséget.

Anyagi támogatás: A közlemény megírása, illetve a kapcsolódó kutatómunka anyagi támogatásban nem részesült.

Szerzői munkamegosztás: J. E., I. M., P. J., K. K.: Adatok gyưjtése. J. E.: Adatok elemzése. J. E.: A közlemény megírása. J. E., K. K: A közlemény javítása. A cikk végleges változatát valamennyi szerző elolvasta és jóváhagyta.

Érdekeltségek: A szerzőknek nincsenek érdekeltségeik.

\section{Irodalom}

[1] Nagy E, Ábrók M, Bartha N, et al. Special application of matrix assisted laser desorption ionization time-of-flight mass spectrometry in clinical microbiological diagnostics. [Mátrix-asszisztált lézer deszorpciós, ionizációs, repülési idő mérésén alapuló tömegspektrometria speciális alkalmazása a klinikai mikrobiológiai diagnosztika területén.] Orv Hetil. 2014; 155: 1495-1503. [Hungarian]

[2] Czirók É. Clinical and epidemiological bacteriology. [Klinikai és járványügyi bakteriológia.] Melánia Kft., Budapest, 1999. [Hungarian]

[3] European Committee on Antimicrobial Susceptibility Testing. Clinical breakpoints, 2017. Available from: http://www.eucast. org/clinical_breakpoints /

[4] Lobo LJ, Tulu Z, Aris RM, et al. Pan-resistant Achromobacter xylosoxidans and Stenotrophomonas maltophilia infection in cystic fibrosis does not reduce survival after lung transplantation. Transplantation 2015; 99: 2196-2202.

[5] Swenson CE, Sadikot RT. Achromobacter respiratory infections. Ann Am Thorac Soc. 2015; 12: 252-258.

[6] Liu C, Pan F, Guo J, et al. Hospital acquired pneumonia due to Achromobacter spp. in a geriatric ward in China: clinical characteristic, genome variability, biofilm production, antibiotic resistance and integron in isolated strains. Front Microbiol. 2016; 7 : 621.

[7] European Committee on Antimicrobial Susceptibility Testing. Expert rules and intrinsic resistance, 2016. Available from: http://www.eucast.org/expert_rules_and_intrinsic_resistance/

[8] Abbott IJ, Peleg AY. Stenotrophomonas, Achromobacter, and nonmelioid Burkbolderia species: antimicrobial resistance and therapeutic strategies. Semin Respir Crit Care Med. 2015; 36: 99110.

[9] Hu Y, Zhu Y, Ma Y, et al. Genomic insights into intrinsic and acquired drug resistance mechanisms in Achromobacter xylosoxidans. Antimicrob Agents Chemother. 2015; 59: 1152-1161.

[10] Sader HS, Jones RN. Antimicrobial susceptibility of uncommonly isolated non-enteric Gram-negative bacilli. Int J Antimicrob Agents 2005; 25: 95-109.

[11] Virok DP, Ábrók M, Szél B, et al. Chryseobacterium gleum - a novel bacterium species detected in neonatal respiratory tract infections. J Matern Fetal Neonatal Med. 2014; 27: 1926-1929.

[12] Soydan S, Ignak S, Unay Demirel O, et al. Chryseobacterium indolegenes infection in a patient with chronic obstructive pulmonary disease. Drug Discov Ther. 2017; 11: 165-167.

[13] Homem de Mello de Souza HA, Dalla-Costa LM, Vicenzi FJ, et al. MALDI-TOF: A useful tool for laboratory identification of uncommon glucose non-fermenting Gram-negative bacteria associated with cystic fibrosis. J Med Microbiol. 2014; 63: 11481153.

[14] Chen FL, Wang GC, Teng SO, et al. Clinical and epidemiological features of Chryseobacterium indologenes infections: analysis of 215 cases. J Microbiol Immunol Infect. 2013; 46: 425-432.

[15] Bilgin H, Sarmis A, Tigen E, et al. Delftia acidovorans: A rare pathogen in immunocompetent and immunocompromised patients. Can J Infect Dis Med Microbiol. 2015; 26: 277-279.

[16] Kang H, Xu X, Fu K, et al. Characterization and genomic analysis of quinolone-resistant Delftia sp. 670 isolated from a patient who died from severe pneumonia. Curr Microbiol. 2015; 71 : 54-61.

[17] Opota O, Diene SM, Bertelli C, et al. Genome of the carbapenemase-producing clinical isolate Elizabethkingia miricola EM_ CHUV and comparative genomics with Elizabethkingia meningoseptica and Elizabethkingia anophelis: evidence for intrinsic multidrug resistance trait of emerging pathogens. Int J Antimicrob Agents 2017; 49: 93-97.

[18] Han MS, Kim H, Lee Y, et al. Relative prevalence and antimicrobial susceptibility of clinical iolates of Elizabethkingia species 
based on 16S rRNA gene sequencing. J Clin Microbiol. 2017; 55: 274-280.

[19] Ryan MP, Adley CC. Ralstonia spp.: emerging global opportunistic pathogens. Eur J Clin Microbiol Infect Dis. 2014; 33: 291304.

[20] Ryan MP, Adley CC. The antibiotic susceptibility of water-based bacteria Ralstonia pickettii and Ralstonia insidiosa. J Med Microbiol. 2013; 62: 1025-1031.

[21] Naik C, Kulkarni H, Darabi A, et al. Ochrobactrum anthropi: a rare cause of pneumonia. J Infect Chemother. 2013; 19: 162165 .

[22] Thoma B, Straube E, Scholz HC, et al. Identification and antimicrobial susceptibilities of Ochrobactrum spp. Int J Med Microbiol. 2009; 299: 209-220.

[23] Tiwari S, Beriha SS. Primary bacteremia caused by Rhizobium radiobacter in neonate: A rare case report. J Clin Diagn Res. 2015; 9: DD01-DD02.

[24] Zhang HP, Fan JM, Huang DH, et al. Clinical and microbiological characteristics of Rhizobium radiobacter infections: six cases report and literature review. Zhonghua Jie $\mathrm{He} \mathrm{He} \mathrm{Hu} \mathrm{Xi}$ Za Zhi 2010; 33: 93-98.

[25] Sood S, Nerurkar V, Malvankar S. Catheter associated bloodstream infection caused by $R$. radiobacter. Indian J Med Microbiol. 2010; 28: 62-64.

[26] Toh HS, Tay HT, Kuar WK, et al. Risk factors associated with Sphingomonas paucimobilis infection. J Microbiol Immunol Infect. 2011 ; 44: 289-295.
[27] Juhász E, Krizsán G, Lengyel G, et al. Infection and colonization by Stenotrophomonas maltophilia: antimicrobial susceptibility and clinical background of strains isolated at a tertiary care centre in Hungary. Ann Clin Microbiol Antimicrob. 2014; 13: 333.

[28] Camargo CH, Ferreira AM, Javaroni E, et al. Microbiological characterization of Delftia acidovorans clinical isolates from patients in an intensive care unit in Brazil. Diagn Microbiol Infect Dis. $2014 ; 80$ : 330-333.

[29] Wenzler E, Fraidenburg DR, Scardina T, et al. Inhaled antibiotics for Gram-negative respiratory infections. Clin Microbiol Rev. 2016; 29: 581-632.

[30] Juhász E, Kovács A, Pongrácz J, et al. In vitro activity of colistin and trimethoprim/sulfamethoxazole against consortia of multidrug resistant non-fermenting Gram-negative bacilli isolated from lower respiratory tract. Jundishapur J Microbiol. 2017; 10: el4034.

[31] Tom SK, Yau YC, Beaudoin T, et al. Effect of high-dose antimicrobials on biofilm growth of Achromobacter species isolated from cystic fibrosis patients. Antimicrob Agents Chemother. 2015; 60: 650-652.

(Juhász Emese dr., Budapest, Üllői út 78/B, I. emelet, 1082 e-mail: juhasz.emese@med.semmelweis-univ.hu)

\section{PÁLYÁZAT}

A Prof. Dr. Romics László Akadémikus Emlékére Alapítvány pályázatot hirdet Magyarországon dolgozó, magyar állampolgárságú, 40 éven aluli orvosok és orvosbiológiai kutatással foglalkozó személyek számára. A nyertes pályázó(k) között $500000 \mathrm{Ft}$ alapítványi adomány kerül kiosztásra.

A pályázat célja: a klinikai gyógyítás vagy orvosi tudományos kutatás területén dolgozók kiemelkedő tudományos tevékenységének elismerése.

Előnyt élveznek azok a pályázók, akik az alapítvány névadójának munkásságát folytatva cardiovascularis és anyagcsere-betegségek területéröl nyújtanak be pályázatot.

A pályázatot természetes személy, saját nevében, magyar nyelven nyújthatja be, a pályázati anyag ábrák nélkül maximum 15000 leütés (karakter) terjedelmű lehet. A pályázathoz mellékelni kell egy rövid szakmai életrajzot.

A pályázat benyújtásának határideje: 2018. január 31. (elbírálásának határideje: 2018. április 30.)

A pályázatot a palyazat@romicsalapitvany.hu e-mail címre pdf formátumban kell benyújtani.

A pályázat benyújtását saját kézzel aláírt és dátummal ellátott levélben kell bejelenteni az alapítvány titkárának címezve (a borítékra írandó cím: dr. Dudás Márta, 1461 Budapest, Pf 62.) könyvelt (ajánlott) küldeményben, mert ezen bejelentés alapján válik hitelessé a pályázat.

Az alapítvány adatairól, működéséről a www.romicsalapitvany.hu honlapon található információ. 